\title{
Evolution of the Grievance System of the European Bank for Reconstruction and Development: Lessons Learnt and Way Forward
}

\author{
Nobert Seiler*
}

\begin{abstract}
Vested with privileges and immunities, international organizations are neither subject to the substantive provisions of national employment law, nor to the jurisdiction of national labour courts or similar domestic judicial authorities for the adjudication of labour disputes. Nevertheless, it is generally recognised that staff members of international organizations are entitled to have their grievances about decisions of the organization concerning their employment be heard by an internal dispute resolution mechanism, including the right to appeal such decisions to a judicial authority for an independent review. As an international organization promoting the rule of law in the countries where it operates, the European Bank for Reconstruction and Development (EBRD) has regularly adapted since its creation its internal dispute resolution mechanism to emerging legal trends, and the ever-increasing requirements of the case law of international administrative tribunals. In the last reform of its internal justice system, initiated in 2017, the EBRD revised the first stage of its system with the aim to enhance its speed and effectiveness, at a reasonable cost for the staff members and the EBRD. Bearing in mind that the main purpose of the first stage is to establish the facts of the matter in dispute and to report the findings and recommendations to the EB RD President for decision, the EBRD has now evolved towards a more inquisitorial process. In force since February 2018, the new first stage of EBRD's internal justice system offers the necessary due process and fairness to staff members for the review of their grievances, without transforming the committee conducting that stage into a quasi-judicial body. After all, the purpose of the first stage of the system is to deliver a report and recommendation to the EBRD President, assisting them in their consideration of the matter in dispute.
\end{abstract}

* Norbert Seiler, Deputy General Counsel, European Bank for Reconstruction and Development (EBRD), seilern@ebrd.com. The contents of this chapter reflect the opinion of the individual author and do not necessarily reflect the views of the EBRD. The author gratefully appreciates the contribution of Elie Raimond, Principal Counsel, EBRD, in the preparation of this chapter.

(C) ASIAN INFRASTRUCTURE INVESTMENT BANK (AIIB), 2021 | DOI:10.1163/9789004441033_010

This is an open access chapter distributed under the terms of the CC-BY-NC 4.o License, 


\section{Introduction}

As the International Court of Justice (ICJ) noted already in 1954 in the Advisory Opinion, Effects of awards of compensation made by the United Nations Administrative Tribunal, it was "inevitable that there would be disputes between the organization and staff members as to their rights and duties". In order to address these disputes, it is widely recognised that the right to an internal dispute resolution mechanism as well as to a subsequent appeal to a judicial authority are safeguards that the staff of international organizations shall enjoy. ${ }^{2}$ Therefore, international organizations not subject to national employment law such as the European Bank for Reconstruction and Development (EBRD), progressively instituted mechanisms with the view to safeguard rights of their staff members, but also to protect their jurisdictional immunity.

In order to protect the rights of staff members, international organizations need to establish processes for the review of staff grievances meeting general principles of fairness and due process. ${ }^{3}$ In this respect, most international administrative tribunals share the same view on the main principles to be observed. For instance, the Administrative Tribunal of the International Labour Organization (ILOAT) has held that an internal appeal process is an "extremely significant element of the entire system of review of administrative decisions affecting the rights of staff", 4 and that "an official should not, in principle, be denied the possibility of having the decision which he or she challenges effectively reviewed by the competent appeal body". ${ }^{5}$ In the same vein, the World Bank Administrative Tribunal (WBAT) has noted that, in conducting its business, an internal review committee "is, of course, bound to follow basic requirements of fairness". ${ }^{6}$

1 ICJ, Effects of Awards 1954, 57. See also Thévenot-Werner 2014, 26.

2 ILOAT, G. (No. 2) v UPU 2017, para 2; see also ILOAT, C. T. v AITIC 2009, para 15; ILOAT, E.E.É. A. $\checkmark$ CTA 2012, para 20 ("the right to an internal appeal is a safeguard which international civil servants enjoy in addition to their right of appeal to a judicial authority. This is especially true since internal appeal bodies may normally allow an appeal on grounds of fairness or advisability, whereas the Tribunal must essentially give a ruling on points of law").

3 Talvik 2014, 63 .

4 ILOAT, O. S. v EPO 2013, para 9. See also Talvik 2014, 63.

5 ILOAT, V. C. $v$ CDE 2012, para 13. See Also Thévenot-Werner 2014, 29.

6 wвAт, Yang-Ro Yoon (No. 12) v IBRD 2010, para 22 ("the Appeals Committee is, of course, bound to follow basic requirements of fairness, but it is not a judicial body that is required to comply with rules of judicial order and process"); see also wBAT, Yang-Ro Yoon (No. 19) $v$ IBRD 2012; Thévenot-Werner 2014, 33. 
The availability of an internal justice system for the review of administrative decisions affecting the rights of staff is also an important safeguard for the jurisdictional immunity of international organizations. It is now well established that, in the absence of adequate judicial review mechanisms, some national courts, on the basis of, notably, international public order principles, will not hesitate to declare themselves competent to adjudicate disputes between international civil servants and their international organizations. For instance, in 2005 and 2014, the French Cour de Cassation held that the jurisdictional immunity of the African Development Bank ${ }^{7}$ and of the Pacific Community 8 does not protect these organizations from proceedings brought by an employee or a former employee of these international organizations in the domestic courts, when no alternative mechanism has been established to hear the employee's complaint. Furthermore, since 1999 and the decisions in Waite and Kennedy $v$ Germany and Beer and Regan $v$ Germany, ${ }^{9}$ it is clear that the European Court of Human Rights (ECtHR) will not hesitate to assess the alternative dispute resolution mechanisms established by international organizations in the light of Article 6(1) of the European Convention on Human Rights $(\mathrm{ECHR}),{ }^{10}$ stipulating the right to a fair trial and the "right to a Court". 11

Court of Cassation of France, $A f \mathrm{DB} v X$ 2005. Unlike the appeal court in the same case, the Court of Cassation decision did not refer to the ECHR but to the international public order.

8 Court of Cassation of France, $x$ v Pacific Community 2014. See also Thévenot-Werner 2014, 26.

$9 \quad$ ECtHR, Waite and Kennedy $v$ Germany 1999, para 67; ECtHR, Beer and Regan $v$ Germany 1999, para 57. For analysis of these judgments see notably Reinish and Weber 2014, 59-100.

10 See also ECtHR, Stichting Mothers of Srebrenica and Others $v$ The Netherlands 2012, para 163. In this case, which related to a dispute between the applicants and the United Nations based on the use by the Security Council of its powers under the UN Charter, the ECtHR reminded that it considered it a "material factor", in determining whether granting an international organisation immunity from domestic jurisdiction was permissible under the Convention, whether the applicants had alternative means to protect effectively their rights under the Convention. However, the ECtHR also made clear that the absence of an alternative remedy is not ipso facto constitutive of a violation of the right of access to a court. While this case provides a useful interpretation of Waite and Kennedy $v$ Germany 1999, it must be underlined that, as recognised by Cogan 2013, 889, '[t]he Court stressed repeatedly in its decision, as it had in previous cases, that the core mission at issue here was of singular importance (the maintenance of international peace and security). Hence, the need for immunity, and the independence that such immunity confers on organizations, was, as a policy matter, critical. Article 6 had to be read accordingly'

11 The right of access to a court was first established as an aspect of the right to a tribunal under art 6 (1) of the Convention in ECtHR, Golderv UK 1975, paras $28-36$. In that case, the Court found the right of access to a court to be an inherent aspect of the safeguards en- 
The purpose of this chapter is to review the development of the internal dispute resolution mechanism of the European Bank for Reconstruction and Development (EBRD) since its inception, in the light of these trends and considerations.

\section{Evolution of the EBRD Internal Dispute Resolution Mechanism Between 1991 and 2018}

The EBRD was established in 1989 by a multilateral treaty, the Agreement Establishing the EBRD, and it commenced operations in April 1991. In the preamble of the Agreement Establishing the EBRD, its members expressly declare their commitment "to the fundamental principles of multiparty democracy, the rule of law, respect for human rights and market economics."12 Furthermore, a majority of EBRD member countries are also signatories of the ECHR. ${ }^{13}$ Throughout its existence, the EBRD has therefore been keenly aware of the increasing judicial scrutiny of international organizations, leading the Bank to continuously adapt its internal justice system for addressing staff grievances.

Already in August 1991, the Bank adopted its Staff Regulations, which expressly called on the President of the EBRD to establish appropriate procedures for the consideration of complaints and grievances of staff. ${ }^{14}$ Consistent with this provision, the President adopted the first version of the Bank's Grievance and Appeals Procedures (GAP) shortly thereafter, in 1992. According to

shrined in art 6, referring to the principles of the rule of law and the avoidance of arbitrary power which underlay much of the ECHR. See ECtHR, Guide on Article 6 of the European Convention on Human Rights 2019, paras 84-125.

12 Agreement Establishing the EBRD, preamble; ICJ, Effects of Awards 1954, 57 ("It would, in the opinion of the Court, hardly be consistent with the expressed aim of the Charter to promote freedom and justice for individuals and with the constant preoccupation of the United Nations Organization to promote this aim that it should afford no judicial or arbitral remedy to its own staff for the settlement of any disputes which may arise between it and them").

13 It is however to be noted that the EBRD itself is not part to the ECHR. In this respect, in a case involving the EPO, the ILOAT held that while " $[\mathrm{t}]$ he Member States of the [Organization] are all signatories to the European Convention on Human Rights, the Organization $[\ldots]$ as such is not a member of the Council of Europe and is not bound by the Convention in the same way as signatory states" (ILOAT, J. M. W. VEPO 2004, para 11).

14 Section 10 of the EBRD Staff Regulations then stated, "Appropriate procedures shall be established by the President for the consideration of complaints and grievances of individual persons on the staff of the Bank on matters involving the consistency of actions taken in their individual cases with the regulations governing personnel and their conditions of service". 
these initial GAP, grievances against decisions affecting the rights of staff members were to be heard by an Appeals Committee consisting of an external legal expert acting as chair, and staff members participating in the proceedings as assessors, some of whom were elected by staff and some appointed by the President. The role of the Appeals Committee was to hear cases, establish the facts of the matter and issue reports and recommendations to the President for final decision. The President was free to accept the recommendations of the Appeals Committee or to depart from them, as long as reasons were provided in his final decision.

The GAP were first revised in 1995, providing for alternates of the elected and appointed staff members serving on the Appeals Committee. The second revision of the GAP, which took place in 1997 following a thorough review of the GAP and after consultations with EBRD's Staff Council, introduced more substantial changes to the appeals process. The revised GAP introduced new procedures for the election of staff representatives on the Appeals Committee as well as the reimbursement of legal expenses of up to G BP 2,500 of grieving staff. Also, and while this commitment was not expressly set out in the rules, the President undertook to accept and implement the recommendations of the Appeals Committee, giving it a de facto decision-making role. Simultaneously, the President approved the establishment of EBRD's Ombudsman function.

In 1999, the Board of Directors of the Bank asked the chair of the Appeals Committee to consider whether the basic objective of the appeals system (to safeguard the employment rights of staff members in a manner that is practical, cost-effective while not prejudicing the Bank's ability to carry out its mandate) was met by the existing arrangements. The report of the chair of the Appeals Committee concluded that the scope of matters that could be considered under the GAP was too narrow and that the Bank should set up a system under which staff members could seek an independent review of substantially all administrative decisions adversely affecting their rights as employees. In order to do so, the Bank had the possibility to arrange for such an independent review either by enabling its staff to submit grievances for adjudication to an administrative tribunal established by another international organization, such as the WBAT or ILOAT, or by establishing its own administrative tribunal. ${ }^{15}$

In light of the conclusions of this report, in 2002, Section 10 of the Staff Regulations was amended and the grievance system was revised, introducing a

15 Amerasinghe 2012 refers to the role played by the WBAт as an inspiration for the creation of the EBRD Administrative Tribunal. 
new administrative tribunal which was to assume the functions of the Appeals Committee. ${ }^{16}$ The newly created EBRD Administrative Tribunal was also chaired by an independent legal expert and supported by staff assessors, some of whom are elected by staff and some appointed by the President. The jurisdiction of the Administrative Tribunal was wider than that of the Appeals Committee, including for the first time grievances of staff on probation and fixed-term contracts and appeals of decisions of committees under the Bank's retirement plans. Unlike the former Appeals Committee, which reported to the President, the Administrative Tribunal rendered decisions in its own right on the matters falling under its jurisdiction.

Following the undertaking given in 2002 by the President to review the new grievance system in the 12-month period following the third anniversary of its implementation, the EBRD carried out another review of the system in 2006. In this exercise, the EBRD again paid attention to the grievance systems established by other international organizations, with a particular focus on other international financial institutions (such as the International Monetary Fund, the World Bank, the Inter-American Development Bank and the Asian Development Bank). Up to this time, the Bank's system featured the Administrative Tribunal as its only tier for the review of management decisions in staff matters giving rise to grievances. Following the review, the Bank decided to follow its peers and established a two-tier system for the review of such decisions, ${ }^{17}$ with a Grievance Committee serving as the first tier, and an Administrative Tribunal as the second and final tier. ${ }^{18}$ The composition and function of the Grievance Committee shared many similarities with the original Appeals

16 EBRD Staff Regulations, s 10 ("Appropriate procedures shall be established by the President in order to consider and address complaints and grievances of individual staff members of the Bank based on individual or regulatory decisions taken by the Bank in relation to their employment, including decisions of any administration committee established in accordance with the rules governing any retirement plan of the Bank. These procedures shall include the creation of an Administrative Tribunal which will have power to make awards in favour of the staff member (or former staff member as the case may be) but not to make any awards inconsistent with any resolutions or decisions adopted or taken by the Board of Governors or the Board of Directors of the Bank").

17 It resulted from the analysis carried out by the EBRD at that time that the World Bank (with the Appeals Committee), the International Monetary Fund (with the Grievance Committee), the Asian Development Bank (with the Appeals Committee) and the InterAmerican Development Bank (with the Conciliation Committee) had set up a system guaranteeing review by a Committee before potential challenge before their respective administrative tribunals.

18 The EBRD did not follow the path previously followed by the ILOAT and the United Nations Administrative Tribunal and allowing the International Court of Justice to act as a final review body in staff member disputes. In this regard, see Gomula 2012. 
Committee - it was chaired by an external legal expert supported by two staff assessors, and its purpose was to hear cases and submit reports and recommendations to the President for decision. Recommendations made by the Grievance Committee were not binding on the President, and grieving staff members were entitled to lodge an appeal against the President's decision before a newly constituted Administrative Tribunal. ${ }^{19}$ The Administrative Tribunal consists of a panel of judges appointed by the Board of Directors of the EBRD on the recommendation of the President, following consultation with the Vice President responsible for Human Resources, the General Counsel and the Staff Council. ${ }^{20}$ It is empowered to take final decisions on all matters before it.

\section{The 2017 Reform and the Creation of the Administrative Review} Committee

In 2017, 11 years after the establishment of the Bank's two-tier system, and following a sharp increase in the number of grievance cases, ${ }^{21}$ the Bank once again embarked on a review of its internal dispute resolution mechanism. The review, which was focused on the first tier of the system, was completed in February 2018 with the entry into force of the new Directive on Administrative Review Process (Directive) and the establishment of the Administrative Review Committee, replacing the Grievance Committee. The second tier of the system continues to operate in accordance with the Appeals Procedures adopted in 2006, which since then have only been amended occasionally to address minor technical aspects.

Just like its predecessor, the now-discontinued Grievance Committee, the Administrative Review Committee consists of a legal professional as its chair, and two assessors from a roster of EBRD staff, some of whom are elected by

19 EBRDAT, Staff Member "A" $v$ EBRD 2017, para 81 ("The Tribunal does not find in the Bank's law any indication that the President is barred from rejecting GC recommendations in whole or in part. To be sure, the President's decision must comply with Bank law and must not be discriminatory, arbitrary or otherwise an abuse of discretion"). See also, EBRDAT, Floriana Bajrami v EBRD 2016, para 16 ("The Tribunal accepts the Bank's argumentation that in accordance with ss 1.03 and 8.01(a) of the Grievance Procedures, GC's recommendations are not mandatory for the Bank's President").

$20 \quad$ EBRD Directive on Appeals Process, s 2.02 (d).

21 The President received six requests for review in 2012, none in 2013 and 2014, seven in 2015, eight in 2016, eight in 2017 and 13 in 2018. 
staff and others appointed by the President. Also like the Grievance Committee, the task of the Administrative Review Committee is to establish the facts giving rise to the grievance, and to submit to the President reports and recommendations for their decision. The main elements of the reform can be summarised as follows.

\subsection{From a Quasi-Adversarial to a More Inquisitorial Process}

The first and essential purpose of the reform carried out in 2017 was to change the fundamental character of the proceedings at the first tier of the Bank's internal dispute resolution system. Indeed, over the years (and perhaps as the result of the influence of chairs familiar with litigation practices in common law systems), Grievance Committee proceedings had become increasingly adversarial, with advocates representing their parties' case or position to the Grievance Committee, offering evidence, examining and cross-examining witnesses, and making written and oral submissions on behalf their clients. For most cases, proceedings started with a directions hearing where the chair of the Grievance Committee asked the parties to identify the evidence they intended to present to the Committee in order to establish the facts.

Therefore, although the Grievance Committee was not designed to be a judicial or quasi-judicial body, and instead was responsible for determining the facts of the matter in dispute and submitting its recommendations for the President's decision, staff members had almost no choice but to engage lawyers and to rely on their support throughout the proceedings before the Committee. These complex proceedings had a deterrent effect on staff members who were reluctant to engage external counsel for an internal procedure. Furthermore, they resulted in considerable financial costs for the Bank since it was the Bank's general practice to cover the legal costs incurred by staff members (even when the staff member did not prevail with the grievance). ${ }^{22}$

A review of the procedures of other international financial organizations revealed that, while certain organizations such as the International Monetary Fund allow staff members to be represented by external legal counsel in the first stage of their internal dispute resolution system, others go the opposite way. For example, the World Bank's staff manual expressly provides that, during the peer review process, the requesting staff member and responding manager are required to draft submissions in their own words and that attorneys may not draft submissions. ${ }^{23}$ In the same vein, the staff manual specifies that

22 Until 2017, legal costs awarded per case ranged from GBP 6,000 up to more than GBP 43,000.

23 World Bank Staff Manual, s 8.04. 
attorneys are not allowed in hearings and that the staff member and manager involved may each be accompanied by an advisor which is a current or former staff member, but who may not be engaged in the practice of law. ${ }^{24}$

As a result of the EBRD's latest reform, while staff members remain free to seek and receive legal advice on their case and to have their submissions prepared by lawyers, ${ }^{25}$ they are not represented by lawyers in Administrative Review Committee proceedings. Members of the Bank's Office of the General Counsel do not appear in proceedings before the Administrative Review Committee on behalf of the Bank and do not participate in any hearing organised by the Administrative Review Committee. ${ }^{26}$

Instead, it is the duty of the Administrative Review Committee to make its own inquiries and to issue directions in order to establish the facts of the cases before it. Like in other inquisitorial proceedings, the Administrative Review Committee is free to hear the parties and conduct its inquiries on the basis of the evidence offered by either party to support their case, and on the basis of any other evidence it considers necessary for its report and recommendation to the President.

Nearly two years following the adoption of the new proceedings, it is evident that the reduced role of lawyers at the first tier has led to a significant reduction in costs, but has also resulted in a moderation of the tone of oral and written submissions to the Administrative Review Committee. As detailed further below, in the absence of external counsel it is also more likely that both parties will be willing to pursue mediation.

\subsection{A Faster and More Efficient Resolution of Internal Disputes}

International organizations are not exempt from observing the legal maxim, justice delayed is justice denied. For example, the ILOAT held that 17 months

24 World Bank Staff Manual, s 8.05.

25 EBRD Directive on Administrative Review Process, s 6.4.2 ("A Staff Member may also seek advice from a person from outside of the Bank, including a lawyer for the drafting of their request for review of an Administrative Decision which is subject to review in accordance with the Administrative Review Process set out in this Directive and for the drafting of any comments and/or expressing views in accordance with paragraph 6.4.2(g) above, subject to such person concluding a confidentiality undertaking [...]").

26 EBRD Directive on Administrative Review Process, s 6.4.2 ("The Staff Member and the representative of the Bank may be accompanied to a meeting with the Administrative Review Committee by a person of their choice, including another current or former staff member, so long as such person is not a lawyer or engaged in the practice of law, the Staff Legal Adviser, a lawyer in Corporate teams of the Office of the General Counsel, or the Ombudsperson"). 
for issuing a report on an internal appeal relating to disciplinary issues was unreasonable and granted the staff member involved substantial damages. ${ }^{27}$

By 2015, the average time required by the EBRD's Grievance Committee to deliver a 'Report and Recommendation' to the President was nearly 15 months (with a minimum of 10 months and a maximum of 21 months). As a consequence, in the interest of both staff members and the Bank, it had become apparent that the Bank had to speed up its process. ${ }^{28}$ The Bank addressed this specific issue by introducing strict procedural timelines for the proceedings of its Administrative Review Committee. The Directive provides that the Administrative Review Committee has 90 working days from its receipt of a request for review (more or less four months) to complete its consideration of the matter and submit a Report and Recommendation to the President for decision. ${ }^{29}$

This is an ambitious procedural constraint and two years after the adoption of the Administrative Review Process, it can be observed that the reform had the effect to substantially speed up the treatment of requests for review. In practice, except in complex cases requiring more fact finding where the Administrative Review Committee requested that the parties submit additional documents or address specific questions, all Administrative Review Committee Reports and Recommendations have been prepared within 90 working days. While the Bank does not formally have the ability to sanction the Administrative Review Committee if a Report is not delivered by the 9o-day deadline,

27 ILOAT, R. (No. 2) v UNESCO 2019, consid 14.

28 See EBRDAT, A. $v$ EBRD 2017, para 51. The Administrative Tribunal criticised the time taken by the Grievance Committee for delivering its report and recommendations, underlining notably that the Grievance Committee had to inform the Appellant about the delay in preparation of its report. Had the applicant asked for such remedies, the Administrative Tribunal then added that it would have granted pecuniary remedies due to that delay.

29 EBRD Directive on Administrative Review Process, s 6.4.2(j) ("The Administrative Review Committee shall take all necessary steps to provide its Report and Recommendation to the President and to the Staff Member as expeditiously as possible, but no later than 90 days after the request for review was referred to the Chair of the Administrative Review Committee by the President, unless the Administrative Review Committee determines that additional time is required and justified in exceptional circumstances beyond its control, such as: (i) significant complexity of the matter under review, requiring a considerable volume of information and/or documentation to be collected and assessed; or (ii) delays, due to objective reasons (e.g. illness, travel), in obtaining essential information either from the Staff Member or the Bank or in obtaining written documentation. In the event that the Administrative Review Committee requires additional time, it shall promptly inform the Staff Member and the Bank in writing, specifying the reasons necessitating the need for additional time"). 
the Bank has significantly accelerated the timeline of the proceedings before the Administrative Review Committee.

\subsection{Streamlining of the Proceedings}

The clarity of procedures is key to their success and to the smooth functioning and effectiveness of a grievance system. ${ }^{30}$ It is indeed essential for international organizations not to create procedural traps or unnecessarily convoluted procedures. As an example, international administrative tribunals such as the Administrative Tribunal of the International Monetary Fund (IMFAT) and the ILOAT notably alerted international organizations to the risks resulting from the multiplication of distinct internal review mechanisms and the subsequent effects on the lack of legal certainly. ${ }^{31}$ For example, the ILOAT expressed its scepticism about the "confusion in the relevant texts, the multiplicity of conflicting remedies and the inability on the part of the existing mechanisms $[\ldots]$ to exercise their $[\ldots]$ powers effectively". ${ }^{2}$

Facing similar issues after decades of regulatory evolution, other international organizations such as the United Nations moved to abolish many of their specialised internal advisory bodies. Instead, creating one single independent body, the management evaluation unit. ${ }^{33}$ After four reforms in the course of more than twenty years, the EBRD encountered similar challenges, with a broad diversity of ways to contest administrative decisions and the unnecessary multiplication of layers of review. For instance, prior to the 2017 reform, every administrative decision had to be challenged first with the Managing Director, Human Resources. When unsatisfied with the outcome of this review, the staff member was then free to submit a new request for review to the Vice President responsible for Human Resources. It was only after receipt of the review decision of the Vice President responsible for Human Resources that the unsatisfied staff member was able to submit a request for review to the President-who in turn referred the matter to the Grievance Committee for its assessment. The multiplication of layers and procedural requirements had a deterrent effect on staff members. For example, the review of the matter by the Vice President responsible for Human Resources following the review and decision by the Managing Director, Human Resources was generally perceived as a mere rubberstamping of that decision. With the adoption of the Directive,

$30 \quad$ Thévenot-Werner 2014, 25.

31 IMFAT, $M$ s. "J" $\nu I M F$, para 89.

32 ILOAT, A. T. $v$ ILO 2004, para 6; see also Thévenot-Werner 2014, 30.

33 For an independent assessment of the new system in place, see UNGA, 'Report of the Interim Independent Assessment Panel' 2016. 
the Bank abolished this second layer of management review. Procedures are now faster and clearer because, unless the challenged administrative decision was taken by the Managing Director, Human Resources, ${ }^{34}$ the matter only needs to be reviewed by the Managing Director, Human Resources and not by the Vice President responsible for Human Resources before the staff member can file a request for review to the President.

The EBRD also simplified the procedures for determining whether requests for review submitted to the President are admissible (for instance, whether or not the required steps prior to such submission to the President have been duly undertaken and completed, whether the applicable time limits have been met and whether the request expressly articulates the outcome and remedies sought by the staff member). Prior to the reform, every request for review had to be referred to the Grievance Committee, even if it was manifestly inadmissible. Then, the Bank had to challenge the competence of the Grievance Committee to hear the matter and enter into a new round of submissions with the staff member on such jurisdiction issues. Therefore, even manifestly inadmissible request for review (such as time barred requests) often gave rise to a time consuming and costly exchange of submissions between the Bank and the staff member.

Under the new system, upon receipt of a request for review, the President has fifteen working days to assess the admissibility of the request for review. Should the President decide that the matter is inadmissible, the staff member will be informed and may file an appeal directly with the Administrative Tribunal. By adopting this mechanism the Bank respects the rights of defence of the staff member without delaying the process and creating unnecessary costs and submissions for the Bank and the staff member.

Last, the Bank worked on the relationship between internal dispute resolution mechanisms and disciplinary proceedings as these two set of rules previously worked independently from each other. The Bank has introduced a provision guaranteeing that any process under the internal appeals procedure will be stayed pending receipt of the outcome of any disciplinary procedure launched in parallel on a related matter by or against the staff member using the internal dispute resolution process.

34 As an example, the decision to transfer a staff member is adopted by the Managing Director, Human Resources so that it will first have to be challenged before the Vice President responsible for Human Resources. 


\subsection{A Step Further Towards a More Frequent Recourse to Mediation}

In multicultural environments such as international organizations where staff members are often informed by different moral sensibilities, engaging into costly and lengthy formal dispute resolution proceedings may not always be the most effective approach to address conflicts between the organization and its staff.

In this respect, the Bank has been following the global trend in international organizations towards the promotion of mediation mechanisms. Indeed, as notably underlined by Gheeta Ravindra, former mediator of the International Monetary Fund, "poorly managed conflict results in enormous costs in the form of wasted management time, higher turnover, lower productivity and formal grievances", 35 and "simply having the option of mediation demonstrates to staff that their concerns are taken seriously and that they are in line with the values of the corporate culture". ${ }^{36}$ Also, in the same vein, the "Report of the Interim Independent Assessment Panel on the System of administration of Justice at the United Nations' makes clear that,

$[\mathrm{M}]$ anagers should be encouraged to respond positively to mediation attempts. The prime consideration for both parties should be that an agreed solution is better than protracted legalistic debates. Conflict resolution is about the continuation of working relationships, not about winning. 37

Until 2017, the EBRD was offering mediation only prior to the filing of formal grievances. However, it was not possible to seek recourse to mediation once a request for review was submitted to the President. Since the reform, mediation is possible at every stage of the process, and can even be suggested as a course of action by the Administrative Review Committee itself. While the new system enhances the possibilities to use mediation, mediation must remain an option dependent on the will of the parties and the Bank has not adopted the approach of other organizations consisting in imposing mediation or conciliation as a preliminary step to any judicial challenge. ${ }^{38}$

35 Ravindra 2014, 35.

36 Ibid, 39 .

37 UNGA, 'Report of the Interim Independent Assessment Panel' 2016, 2.

38 See for instance, Е в в Staff Regulations, art 41 (requiring that, prior to initiating any proceedings before the Court of Justice of the European Union, an amicable settlement shall be sought and a request for conciliation made). 


\subsection{Towards More Transparency and Legal Certainty}

Prior to the 2017 reform, an abstract of every Report and Recommendation issued by the Grievance Committee was published on the intranet of the Bank. However, staff members did not have access to the (redacted) subsequent decision taken by the President after consideration of this Report, so that no great clarity was given to staff members about the Bank's position in the matters in dispute. Following the reform, a summary abstract of the Report and Recommendation is still published, but it is accompanied by the subsequent decision of the President (in a redacted form). Staff members can now stay abreast of the Bank's legal position on the issues which have given rise to grievance proceedings.

Along with the main points of the 2017 reform discussed above, the EBRD has made a series of miscellaneous additional changes to its first-tier proceedings. For example, staff members now have an express duty to cooperate with the Administrative Review Committee; all time limits are now expressed in working days while the previous rules offered a potentially misleading combination of days and months; last but not least, the previous system permitted the President to review regulatory decisions taken by the Board of Directors or the Board of Governors of the Bank (composed of Finance Ministers of member countries). This anomaly has been corrected in the new proceedings, and regulatory decisions taken by the President, the Board of Directors or the Board of Governors can only be challenged in the EBRD Administrative Tribunal. ${ }^{39}$

\section{$4 \quad$ Conclusion}

As an international organization promoting the rule of law in the countries where it operates, the EBRD has adjusted its own internal dispute resolution system over time to satisfy prevailing international standards, taking into account emerging legal trends as well as the case law of international administrative tribunals.

Following the latest reform, the Bank benefits from a system delivering both legal certainly and procedural flexibility, at a reasonable cost for the Bank and staff member. While there is always room for improvement, the current system provides staff members with the necessary due process and fairness protection, without transforming the committee conducting the first-tier review for the consideration of the President into a quasi-judicial body.

39 This is also the case for individual decisions taken by the committees established under the retirement plans of the Bank. 


\section{Reference List}

A. T. v International Labour Organization, ILOAT Judgment No 2307 (2004).

A. $v$ European Bank for Reconstruction and Development, EBRDAT Decision No 2017/AT/o6 (2017).

African Development Bank v X, Court of Cassation, 25 January 2005, No 04-41012, ILDC 778 (FR 2005).

Agreement Establishing the European Bank for Reconstruction and Development (29 May 1990, entered into force 28 March 1991).

Amerasinghe C F, 'Reflections on the Internal Justice System of International Organisations' in Elias $\mathrm{O}$ (ed), The Development and Effectiveness of International Administrative Law - On the Occasion of the Thirtieth Anniversary of the World Bank Administrative Tribunal (Martinus Nijhoff Publishers 2012).

Beer and Regan v Germany App No 28934/95 (ECtHR, 18 February 1999).

C. T. $v$ Agency for International Trade Information and Cooperation, ILOAT Judgment No 2781 (2009).

Cogan J K, 'Stichting Mothers of Srebrenica v. Netherlands' (2013) 107(4) The American Journal of International Law 884.

E.E.É. A. v Technical Centre for Agricultural and Rural Cooperation, ILOAT Judgment No 3067 (2012).

Effect of Awards of Compensation Made by the United Nations Administrative Tribunal (Advisory Opinion) [1954] ICJ Rep 47.

European Bank for Reconstruction and Development, Directive on Administrative Review Process.

European Bank for Reconstruction and Development, Directive on Appeals Process.

European Bank for Reconstruction and Development, Staff Regulations.

European Court of Human Rights, Guide on Article 6 of the European Convention on Human Rights: Right to a Fair Trial (Civil Limb) (ECtHR, updated 31 August 2019) <https://www.echr.coe.int/Documents/Guide_Art_6_ENG.pdf> accessed 4 March 2020.

European Investment Bank, Staff Regulations.

Floriana Bajrami v European Bank for Reconstruction and Development, EB RDAT Decision No 2016/AT/o2.

G. (No. 2) v Universal Postal Union, ILOAT Judgment No 3732 (2017).

Golder $v$ The United Kingdom App No 4451/70 (ECtHR, 21 February 1975).

Gomula J, 'The Review of Decisions of International Administrative Tribunals by the International Court of Justice' in Elias O (ed), The Development and Effectiveness of International Administrative Law-On the Occasion of the Thirtieth Anniversary of the World Bank Administrative Tribunal (Martinus Nijhoff Publishers 2012).

J. M. W. v European Patent Organisation, ILOAT Judgment No 2292 (2004). 
Ms. "J" $v$ International Monetary Fund, IMFAT Judgment No 2003-1 (2003).

O. S. v European Patent Organisation, ILOAT Judgment No 3229 (2013).

Ravindra G, 'The Cost of Conflict and the Need for Conflict Competent Organizations' in Talvik A (ed), Best Practices in Resolving Employment Disputes in International Organizations (ILO Geneva 2014).

Reinisch A and Weber U A, 'In the Shadow of Waite and Kennedy: The Jurisdictional Immunity of International Organizations, the Individual's Right of Access to the Courts and Administrative Tribunals as Alternative Means of Dispute Settlement' (2004) 1 International Organizations Law Review 59.

R. (No. 2) v UNESCO, ILOAT Judgment No 4063 (2019).

Staff Member "A" $v$ European Bank for Reconstruction and Development, EBRDAT Decision No 2017/AT/05 (1).

Stichting Mothers of Srebrenica and Others $v$ The Netherlands App No 65542/12 (ECtHR, 8 October 2012).

Talvik A, 'The ILO Administrative Tribunal: Shaping the Internal Review Process' in Talvik A (ed), Best Practices in Resolving Employment Disputes in International Organizations (ILO Geneva 2014).

Thévenot-Werner A, 'The Need to Develop Effective Individual Dispute Resolution Mechanisms Prior to Judicial Appeals in International Organizations' in Talvik A (ed), Best Practices in Resolving Employment Disputes in International Organizations (ILO Geneva 2014).

United Nations General Assembly, 'Report of the Interim Independent Assessment Panel on the System of Administration of Justice at the United Nations' (15 April 2016) UN Doc A/71/62/Rev.1.

V. C. $v$ Centre for the Development of Enterprise, ILOAT Judgment No 3127 (2012).

Waite and Kennedy $v$ Germany App No 26083/94 (ECtHR, 18 February 1999).

World Bank, Staff Manual.

$X v$ Pacific Community, Court of Cassation (Social Chamber), 13 May 2014, Application No 12-23805.

Yang-Ro Yoon (No. 12) v International Bank for Reconstruction and Development, WBAT Decision No 436 (2010).

Yang-Ro Yoon (No. 19) $v$ International Bank for Reconstruction and Development, WBAT Order No 2012-3 (2012). 